\title{
Recent Advances in Visible-Light-Driven Photoelectrochemical Water Splitting: Catalyst Nanostructures and Reaction Systems
}

\author{
Xiaoping Chen ${ }^{1,2} \cdot$ Zhixiang Zhang ${ }^{1,2} \cdot$ Lina Chi $^{2,3} \cdot$ Aathira Krishnadas Nair ${ }^{2}$. \\ Wenfeng Shangguan ${ }^{1} \cdot$ Zheng Jiang $^{2}$
}

Received: 17 August 2015/Accepted: 31 August 2015/Published online: 28 October 2015

(C) The Author(s) 2015. This article is published with open access at Springerlink.com

\begin{abstract}
Photoelectrochemical (PEC) water splitting using solar energy has attracted great attention for generation of renewable hydrogen with less carbon footprint, while there are enormous challenges that still remain for improving solar energy water splitting efficiency, due to limited light harvesting, energy loss associated to fast recombination of photogenerated charge carriers, as well as electrode degradation. This overview focuses on the recent development about catalyst nanomaterials and nanostructures in different PEC water splitting systems. As photoanode, Au nanoparticle-decorated $\mathrm{TiO}_{2}$ nanowire electrodes exhibited enhanced photoactivity in both the UV and the visible regions due to surface plasmon resonance of Au and showed the largest photocurrent generation of up to $710 \mathrm{~nm}$. Pt/CdS/CGSe electrodes were developed as photocathode. With the role of $\mathrm{p}-\mathrm{n}$ heterojunction, the photoelectrode showed high stability and evolved hydrogen continuously for more than 10 days. Further, in the $\mathrm{Z}$-scheme system $\left(\mathrm{Bi}_{2} \mathrm{~S}_{3} / \mathrm{TNA}\right.$ as photoanode and $\mathrm{Pt} / \mathrm{SiPVC}$ as photocathode at the same time), a self-bias (open-circuit voltage $V_{\mathrm{oc}}=0.766 \mathrm{~V}$ ) was formed between two photoelectrodes, which could facilitate photogenerated charge transfers and enhance the photoelectrochemical performance, and which might provide new hints for PEC water splitting. Meanwhile, the existing problems and prospective solutions have also been reviewed.
\end{abstract}

Keywords Photoelectrochemical water splitting $\cdot$ Nanostructures $\cdot$ Reaction system $\cdot$ Heterojuction $\cdot$ Hybrid systems

\section{Introduction}

The energy consumption nowadays to maintain modern lifestyle of mankind mainly relies on primary fossil fuels such as oil, coal, natural gas, etc. However, the fossil

Wenfeng Shangguan

shangguang@sjtu.edu.cn

$\triangle$ Zheng Jiang

Z.Jiang@ @oton.ac.uk

1 Research Center for Combustion and Environment Technology, Shanghai Jiao Tong University, Shanghai 200240, People's Republic of China

2 Faculty of Engineering and the Environment, University of Southampton, Highfield, Southampton SO17 1BJ, UK

3 School of Environmental Science and Technology, Shanghai Jiao Tong University, Shanghai 200240,

People's Republic of China fuels are suffering from accelerated depletion and bringing about serious environmental issues and threats to global climate. It is a mission of international scale to explore and utilize alternative energy to compensate for the consumption of fossil fuels and mitigate the corresponding climate changes. Among various alternative energies, hydrogen has been considered as a promising candidate to solve aforementioned problems because it is a source of green and renewable energy. There are a variety of strategies for hydrogen production, such as electrolysis, thermal water splitting, cracking of petroleum, hydrocarbon reforming, etc. However, these techniques are either costly or rely on fossil fuels. In 1972, Fukushima and Honda discovered photoelectrochemical (PEC) water splitting in which hydrogen and oxygen were released, respectively, from titanium dioxide $\left(\mathrm{TiO}_{2}\right)$ photoelectrode and Platinum $(\mathrm{Pt})$ counter electrode under ultraviolet (UV) light irradiation [1], revealing the potential of solar energy water splitting to produce 
sustainable hydrogen. This discovery stimulated great interest to explore effective photoelectrode materials for solar energy hydrogen generation via solar energy water splitting which is not only a clean process but also stores solar energy in hydrogen [2-4]. However, the widespread application of PEC water splitting still demands great efforts in the discovery of effective photocatalysts and coating process.

In comparison with photocatalytic water splitting using heterogeneous powder semiconductors, PEC water splitting possesses great advantages in (i) the external or self-bias voltage can suppress recombination of photogenerated charge carriers and thus improve the separation and transfer of excited electron-hole pairs of the photocatalysts; (ii) hydrogen and oxygen can be easily separated via collection at different photoelectrodes; (iii) semiconductor films are coated on the conductive substrates, which favors scale up for industrial application in the future; and (iv) last, but not the least, it does not need stirring, so it consumes less power relative to powder photocatalytic water splitting systems [2, 5]. In practice, the performance of PEC water splitting system is dominated by the properties of the semiconductor photocatalysts that harvest solar energy for hydrogen generation.

Various effective UV-light-responsive photocatalysts have been well established [6,7], although most of them suffer from photocorrosion and are not active under visible light which accounts for $45 \%$ energy of solar spectrum, nearly an order of solar energy in UV region. In the recent decades, designing visible-light-driven photocatalysts for water splitting represents a major mission for photocatalytic water splitting to maximize the solar energy conversion and storage. For instance, the metal sulfides have been found as a class of efficient photocatalysts but require sacrificial agents to reduce photocorrosion [8-12]. (Oxy) nitride semiconductors recently emerged as new type of phototcatalysts for visible-light-responsive photocatalytic water splitting [1315], whereas they can respond to short-wavelength visible light with rather low solar energy conversion efficiency. Fortunately, the hybrid photocatalyst systems have demonstrated enhanced water splitting efficiency, which, however, require dedicated design and alignment of the corresponding photocatalytic materials [6].

In this study, we briefly overviewed the recent research advances in the field of hydrogen evolution from PEC water splitting, addressing the different PEC water splitting systems and corresponding electrode materials. Key issues and challenges involved in PEC water splitting systems and potential solutions were highlighted via the comparison of various photoelectrode materials and nanostructures.

\section{Working Principle of Photoelectrochemical Water Splitting}

Loaded with semiconductor photocatalysts, the conductive electrode substrates can be metal plates, silicon substrates, or glass coated with conductive layers, such as fluorine-doped tin oxide (FTO) and indium tin oxide (ITO) [16-19]. In PEC water splitting system, the free energy change $(\Delta G)$ is $237.2 \mathrm{~kJ} \mathrm{~mol}^{-1}$ for converting one molecule of $\mathrm{H}_{2} \mathrm{O}-\mathrm{H}_{2}$ and $1 / 2 \mathrm{O}_{2}$ under standard condition. When a photoelectrode is immersed in an electrolyte solution, electron transfer takes place between the semiconductor and the electrolyte solution so that the Fermi level is equilibrated with the redox potential of electrolyte solution [15]. With n-type semiconductors as working photoanodes, for example, as shown in Fig. 1, photoexcited holes on the semiconductors would oxidize water and produce oxygen, while electrons are transferred to the counter electrode to generate hydrogen. Sometimes, an external voltage is needed to compensate for the potential deficiency, which can also accelerate the separation of excited charges. The electrolytes are essential in the PEC system for charge transfers, which usually are $\mathrm{NaOH}, \mathrm{Na}_{2}$ $\mathrm{SO}_{4}$, etc. [20, 21]. Some sulfides and organic agents can also serve as electrolytes [19, 22]; where there is no oxygen evolution, as water oxidation potential is more positive than the oxidation potential of these materials.

\section{Semiconductors Systems for PEC Water Splitting}

Different semiconductor systems for PEC water splitting and their PEC performance are shown as in Table 1. They can be classified into three groups: (1) photoanode, (2) photocathode, and (3) Z-scheme system for PEC water splitting.

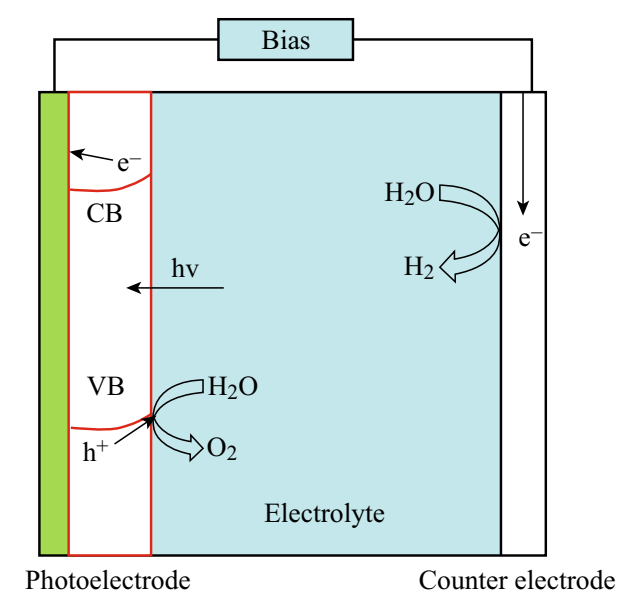

Fig. 1 The schematic setup of PEC water splitting system 
Table 1 Different photoelectrodes and their photoelectrochemical performance

\begin{tabular}{|c|c|c|c|}
\hline Photoelectrode & $\begin{array}{l}\text { Photocurrent } \\
\left(\mathrm{mA} \mathrm{cm}{ }^{-2}\right)\end{array}$ & Experimental condition & Reference \\
\hline $\mathrm{TiO}_{2-x} \mathrm{C}_{x}$ nanotube array & 1.0 & $\begin{array}{l}0 \mathrm{~V} \text { versus } \mathrm{Ag} / \mathrm{AgCl}, 1 \mathrm{M} \mathrm{KOH}(\mathrm{aq}), 2500 \mathrm{~W} \text { Xe lamp }\left(100 \mathrm{mw} \mathrm{cm}^{-2}\right) \text {, } \\
>420 \mathrm{~nm}\end{array}$ & 35 \\
\hline $\mathrm{N}$-doped $\mathrm{TiO}_{2}$ nanotube arrays & 0.182 & $\begin{array}{l}0 \mathrm{~V} \text { versus calomel electrode, } 0.01 \mathrm{M} \mathrm{Na}_{2} \mathrm{SO}_{4}(\mathrm{aq}), 250 \mathrm{~W} \text { halogen lamp, } \\
>400 \mathrm{~nm}\end{array}$ & 36 \\
\hline $\mathrm{S}$-doped $\mathrm{TiO}_{2}$ nanotube arrays & 0.41 & $\begin{array}{l}0.1 \mathrm{~V} \text { versus } \mathrm{SCE}, 0.1 \mathrm{M} \mathrm{Na}_{2} \mathrm{SO}_{4}(\mathrm{aq}), 50 \mathrm{~W} \text { fiber optic illuninator, } \\
>400 \mathrm{~nm}\end{array}$ & 37 \\
\hline $\begin{array}{l}\text { Au nanoparticle-decorated } \mathrm{TiO}_{2} \\
\text { nanowire electrodes }\end{array}$ & 1.49 & $\begin{array}{l}0 \mathrm{~V} \text { versus } \mathrm{Ag} / \mathrm{AgCl}, 1 \mathrm{M} \mathrm{NaOH}(\mathrm{aq}) \text {, white-light illumination }(100 \mathrm{~mW} \\
\mathrm{cm}^{-2} \text { ) }\end{array}$ & 40 \\
\hline $\begin{array}{l}\text { Au decorated } \mathrm{ZnO} \text { nanowire } \\
\text { arrays }\end{array}$ & 1.5 & $\begin{array}{l}1 \mathrm{~V} \text { versus RHE, } 0.5 \mathrm{M} \mathrm{Na}_{2} \mathrm{SO}_{4}(\mathrm{aq}), 300 \mathrm{~W} \text { Xe lamp }\left(100 \mathrm{~mW} \mathrm{~cm}{ }^{-2}\right) \text {, } \\
>420 \mathrm{~nm}\end{array}$ & 42 \\
\hline $\mathrm{CdTe} / \mathrm{TiO}_{2}$ & 0.44 & $\begin{array}{l}0 \mathrm{~V} \text { versus } \mathrm{Ag} / \mathrm{AgCl}, 0.6 \mathrm{M} \mathrm{Na}_{2} \mathrm{~S}(\mathrm{aq}), 300 \mathrm{~W} \mathrm{Xe} \text { arc lamp } \\
\left(6.0 \mathrm{~W} \mathrm{~cm}^{-2}>400 \mathrm{~nm}\right.\end{array}$ & 43 \\
\hline $\mathrm{CdS} / \mathrm{TiO}_{2}$ & 5.6 & $\begin{array}{l}0 \mathrm{~V} \text { versus } \mathrm{Ag} / \mathrm{AgCl}, 0.1 \mathrm{M} \mathrm{Na}_{2} \mathrm{~S}(\mathrm{aq}), 300 \mathrm{~W} \text { Oriel solar simulator (100 } \\
\mathrm{mW} \mathrm{cm}{ }^{-2} \text { ) }\end{array}$ & 46 \\
\hline $\mathrm{Bi}_{2} \mathrm{WO}_{6} / \mathrm{TiO}_{2}$ & 0.014 & $1 \mathrm{~V}$ versus $\mathrm{Ag} / \mathrm{AgCl}, 0.5 \mathrm{M} \mathrm{Na}_{2} \mathrm{SO}_{4}(\mathrm{aq}), 300 \mathrm{~W}$ Xe lamp, $>420 \mathrm{~nm}$ & 47 \\
\hline $\mathrm{CdS} / \mathrm{TiO}_{2} / \mathrm{WO}_{3}$ & 1.6 & $0 \mathrm{~V}$ versus $\mathrm{Ag} / \mathrm{AgCl}, 0.05 \mathrm{M} \mathrm{Na}_{2} \mathrm{~S}(\mathrm{aq}), 300 \mathrm{~W}$ Xe lamp, $>495 \mathrm{~nm}$ & 50 \\
\hline $\begin{array}{l}\text { Hydrogen-treated } \mathrm{TiO}_{2} \\
\text { nanowire arrays }\end{array}$ & 1.97 & $\begin{array}{l}-0.6 \mathrm{~V} \text { versus } \mathrm{Ag} / \mathrm{AgCl}, 1 \mathrm{M} \mathrm{NaOH}(\mathrm{aq}), 150 \mathrm{~W} \text { Xe lamp }(100 \mathrm{~mW} \\
\mathrm{cm}^{-2} \text { ) }\end{array}$ & 52 \\
\hline $\mathrm{N}$-doped $\mathrm{ZnO}$ nanowire arrays & $\sim 0.15$ & $\begin{array}{l}0.5 \mathrm{~V} \text { versus NHE, } 0.5 \mathrm{M} \mathrm{NaClO}_{4}(\mathrm{aq}) \text {, white light source }(100 \mathrm{~mW} \\
\mathrm{cm}^{-2} \text { ) }\end{array}$ & 56 \\
\hline $\mathrm{WO}_{3} / \mathrm{BiVO}_{4}$ & 0.8 & $\begin{array}{l}0.5 \mathrm{~V} \text { versus NHE, } 0.5 \mathrm{M} \mathrm{Na}_{2} \mathrm{SO}_{4}(\mathrm{aq}) \text {, chopped white light }(100 \mathrm{~mW} \\
\mathrm{cm}^{-2} \text { ) }\end{array}$ & 58 \\
\hline $\mathrm{FeOOH}$ & 10 & $\begin{array}{l}0.55 \mathrm{~V} \text { versus RHE, } 1 \mathrm{M} \mathrm{Na}_{2} \mathrm{CO}_{3}(\mathrm{aq}), 150 \mathrm{~W} \text { Xe arc lamp }(100 \mathrm{~mW} \\
\left.\mathrm{cm}^{-2}\right),>400 \mathrm{~nm}\end{array}$ & 60 \\
\hline $\mathrm{IrO}_{2} \cdot \mathrm{nH}_{2} \mathrm{O} / \mathrm{TaON}$ & $\sim 3.75$ & $0.6 \mathrm{~V}$ versus $\mathrm{Ag} / \mathrm{AgCl}, 0.1 \mathrm{M} \mathrm{Na}_{2} \mathrm{SO}_{4}(\mathrm{aq})$, chopped visible light & 65 \\
\hline $\mathrm{IrO}_{2}$-loaded $\mathrm{Ta}_{3} \mathrm{~N}_{5}$ & 3.6 & $0.6 \mathrm{~V}$ versus $\mathrm{Ag} / \mathrm{AgCl}, 0.1 \mathrm{M} \mathrm{Na}_{2} \mathrm{SO}_{4}(\mathrm{aq}), 300 \mathrm{~W} \mathrm{Xe}$ lamp, $>400 \mathrm{~nm}$ & 67 \\
\hline $\begin{array}{l}\mathrm{TiO}_{2} \text { nanoarrays sensitized with } \\
\text { CdS quantum dots }\end{array}$ & 3.98 & $\begin{array}{l}0 \mathrm{~V} \text { versus } \mathrm{Ag} / \mathrm{AgCl}, 1.0 \mathrm{M} \mathrm{KOH} \mathrm{(aq),} 300 \mathrm{~W} \text { Xe lamp }\left(100 \mathrm{~mW} \mathrm{~cm}^{-2}\right) \text {, } \\
>420 \mathrm{~nm}\end{array}$ & 68 \\
\hline $\mathrm{Pt}-\mathrm{In}_{2} \mathrm{~S}_{3} / \mathrm{CuInS}_{2}$ & -17.5 to -7.0 & $0 \mathrm{~V}$ versus RHE, $0.1 \mathrm{M} \mathrm{Na}_{2} \mathrm{SO}_{4}(\mathrm{aq}), 300 \mathrm{~W}$ Xe lamp & 74 \\
\hline $\mathrm{Pt}-\mathrm{CdS} / \mathrm{CuGaSe}_{2}$ & -3.2 & $\begin{array}{l}0 \mathrm{~V} \text { versus RHE, } 0.05 \mathrm{M} \mathrm{Na}_{2} \mathrm{HPO}_{4}(\mathrm{aq})+0.05 \mathrm{M} \mathrm{NaH}_{2} \mathrm{PO}_{4}(\mathrm{aq}), 150 \mathrm{~W} \\
\text { Xe lamp }\end{array}$ & 18 \\
\hline $\mathrm{p}-\mathrm{n} \mathrm{Cu}_{2} \mathrm{O}$ homojuction & -0.2 & $0 \mathrm{~V}$ versus $\mathrm{NHE}, 0.5 \mathrm{M} \mathrm{Na}_{2} \mathrm{SO}_{4}(\mathrm{aq}), 500 \mathrm{~W}$ Xe lamp & 79 \\
\hline $\mathrm{Pt} / \mathrm{ZnO}, \mathrm{Al}_{2} \mathrm{O}_{3}, \mathrm{TiO}_{2} / \mathrm{Cu}_{2} \mathrm{O}$ & -7.6 & $\begin{array}{l}0 \mathrm{~V} \text { versus RHE, } 1 \mathrm{M} \mathrm{Na}_{2} \mathrm{SO}_{4}(\mathrm{aq}), 500 \mathrm{~W} \text { Xe lamp }\left(100 \mathrm{~mW} \mathrm{~cm}^{-2}\right) \text {, } \\
\text { visible light }\end{array}$ & 80 \\
\hline $\begin{array}{l}\text { Photoanode: } \mathrm{TiO}_{2} \\
\text { Photocathode: } \mathrm{CaFe}_{2} \mathrm{O}_{4}\end{array}$ & 0.2 & $0 \mathrm{~V}$ versus $\mathrm{Ag} / \mathrm{AgCl}, 1 \mathrm{M} \mathrm{NaOH}(\mathrm{aq}), 500 \mathrm{~W}$ Xe lamp & 83 \\
\hline $\begin{array}{l}\text { Photoanode: } \mathrm{WO}_{3} \\
\text { Photocathode: } \mathrm{GaInP}_{2}\end{array}$ & 0.02 & $\begin{array}{l}3 \mathrm{M} \mathrm{H}_{2} \mathrm{SO}_{4}(\mathrm{aq}), 250 \mathrm{~W} \text { Oriel tungsten-halogen quartz lamp }(200 \mathrm{~mW} \\
\left.\mathrm{cm}^{-2}\right)\end{array}$ & 84 \\
\hline $\begin{array}{l}\text { Photoanode: } \mathrm{Bi}_{2} \mathrm{~S}_{3} / \mathrm{TNA} \\
\text { Photocathode: } \mathrm{Pt} / \mathrm{SiPVC}\end{array}$ & 1.6 & $\begin{array}{l}0 \mathrm{~V} \text { versus } \mathrm{Ag} / \mathrm{AgCl}, 0.25 \mathrm{M} \mathrm{Na}_{2} \mathrm{~S}+0.125 \mathrm{M} \mathrm{Na}_{2} \mathrm{SO}_{3} \text {, Xe lamp (100 } \\
\left.\mathrm{mW} \mathrm{cm}{ }^{-2}\right),>400 \mathrm{~nm}\end{array}$ & 19 \\
\hline
\end{tabular}

\subsection{Photoanode and Anodic Semiconductors}

In the PEC water splitting setup, photoanode usually comprises n-type semiconductors coated on conductive substrates $[15,19]$. Under light illumination, photoexcited holes accumulate on the surface of the photoanode semiconductors and are consumed in oxidation reactions, while electrons are transferred to a counter electrode via an external circuit as shown in Fig. 2 [15]. From the electrochemical potential point of view, the valence band edge of the photocatalysts should be more positive than the oxygen evolution potential enabling the photoanode to generate oxygen. As one of the significant advantages of PEC, external voltage bias may be applied to compensate for the potential deficiency and accelerate the separation of excited charge carriers, although zero bias is desirable once the PEC systems become well aligned with suitable semiconductor materials. Starting with traditional $\mathrm{TiO}_{2}$ 


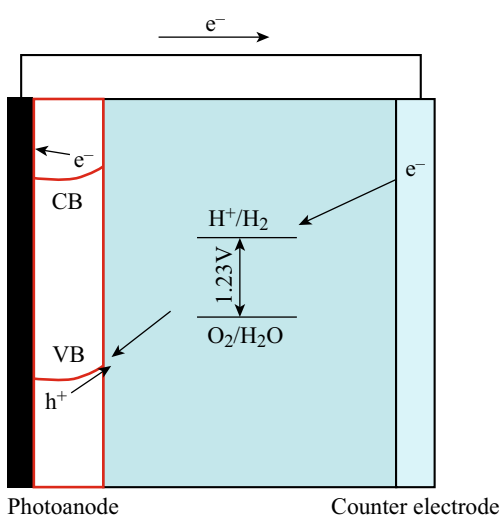

Fig. 2 Semiconductors coated on substrate as photoanode for PEC water splitting [15]

photoanode, this section highlights the recent advances in photoanodes composed of one-dimensional (1D) $\mathrm{TiO}_{2}$ and various hybrid photoanode systems (Fig. 3).

Titanium dioxide $\left(\mathrm{TiO}_{2}\right)$ is the most attempted n-type semiconductor for PEC water splitting due to its low cost, and better chemical and optical stability [23-26]. Among various nanostructured $\mathrm{TiO}_{2}, 1 \mathrm{D}$ titanium dioxide nanotube arrays (TNAs) have gained much attention due to their intrinsic large surface area and unidirectional flow of charges $[24,27]$. TNA can be easily fabricated via anodization of metal titanium foil or plate with great potential for large-scale application [24, 27-29]. 1D $\mathrm{TiO}_{2}$ nanowire arrays were also coated on transparent conducting oxide (TCO)-coated glass through a mild hydrothermal reaction [30]. The photoconversion efficiencies of N719 dye-sensitized solar cells fabricated with the 1D nanowire arrays can be up to $5.02 \%$, which is much higher than those fabricated with the simple $\mathrm{TiO}_{2}$ powders. Titanium dioxide itself shows low photoelectrochemical activity since it is not responsive to visible light due to wide bandgap $(\sim 3.2 \mathrm{eV})$. In order to enhance the visible light absorption, researchers have developed various strategies including doping $\mathrm{TiO}_{2}$ with metal or non-metal, construction of heterojunction, and hydrogenation, or creation of structural vacancies [31-33]. Doping with metal or/and non-metal (C, N, S, B, etc.) was started in the earlytwenty-first century as an effective solution to narrow the bandgap of $\mathrm{TiO}_{2}$ for enhancing PEC efficiency [6, 34-39]. Metal doping and non-metal doping can lead to the conduct band and the valence band increases of acceptor, respectively, which narrowed the bandgap of the photocatalysts and make the photocatalysts respond to visible light. Park et al. prepared carbon-doped $\mathrm{TiO}_{2}$ nanotube arrays with high aspect ratios. The total photocurrent was more than 20 times higher than that with a P-25 nanoparticulate film under white-light illumination [35]. Recently, surface plasmon resonance has been applied in PEC water splitting with extend light absorbance in the entire UV-Visible region [40-42]. Surface plasmon resonance is an intrinsic property of metal nanoparticles, in which the oscillation frequency is highly sensitive to the metal size and shape as well as the dielectric constant of the surrounding environment. For instance, Au nanoparticle-decorated $\mathrm{TiO}_{2}$ nanowire electrodes showed the largest photocurrent generation at $710 \mathrm{~nm}$ and enhanced photoactivity across the entire UV-Visible region, which is due to the excitation of surface plasmon resonance of $\mathrm{Au}$ [40].

Modifying $\mathrm{TiO}_{2}$ nano-semiconductor with second nanosemiconductor of lower bandgap to form heterojunction represents another promising route to harvest visible light. The second nano-semiconductor serves as a photosensitizer and builder for internal electric field across the interface. The internal potential bias significantly promotes the excited electrons and holes' separation and transportation across the interface of the dual photocatalysts, leading to reducing recombination. For instance, $\mathrm{TiO}_{2}$ nanotube arrays (TNAs) were always modified with p-type CdTe and $\mathrm{Cu}_{2} \mathrm{O}$ semiconductors [43-45]. $\mathrm{TiO}_{2}$ is n-type semiconductor. $\mathrm{CdTe}$ and $\mathrm{Cu}_{2} \mathrm{O}$ are p-type semiconductors. Thus, $\mathrm{p}-\mathrm{n}$ junctions can be formed between them, respectively, which facilitate the separation of the excited electrons and holes. Some heterojunctions can enhance the
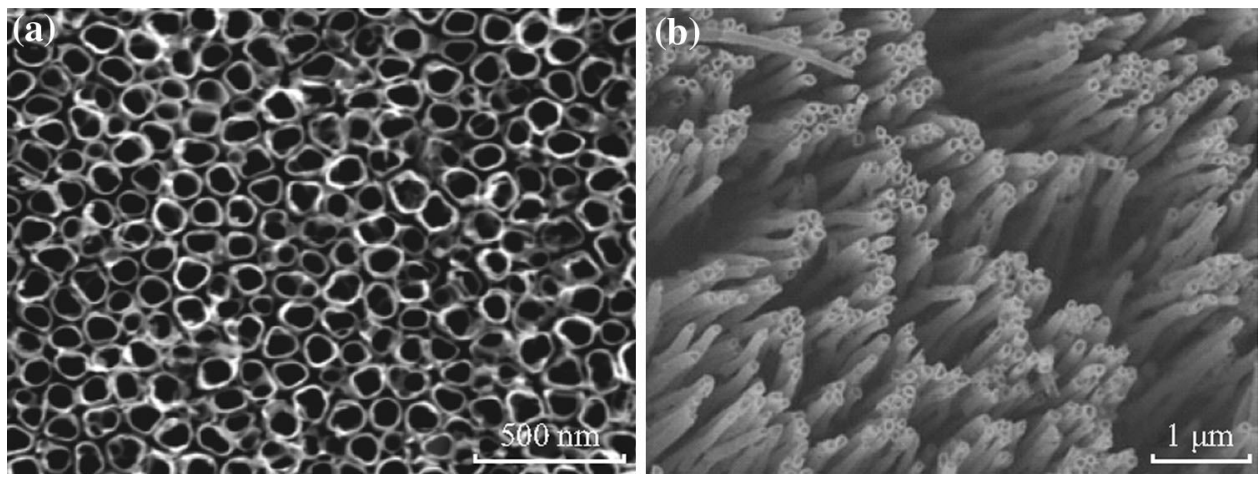

Fig. 3 SEM images of titanium dioxide arrays [29, 34] 


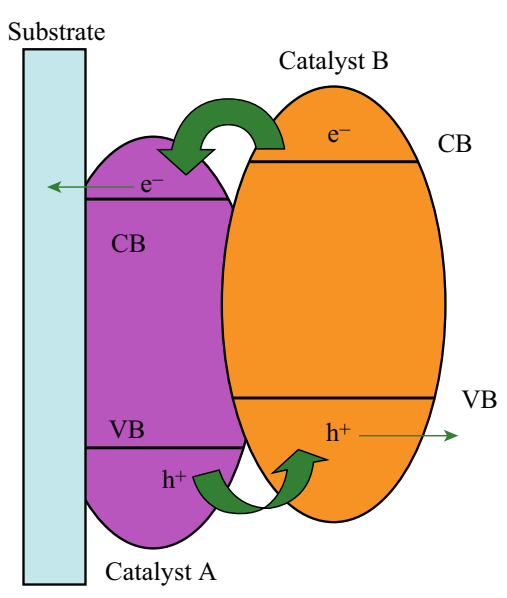

Fig. 4 The overlapping in band gaps between two different photocatalysts and the electron-trap mechanism

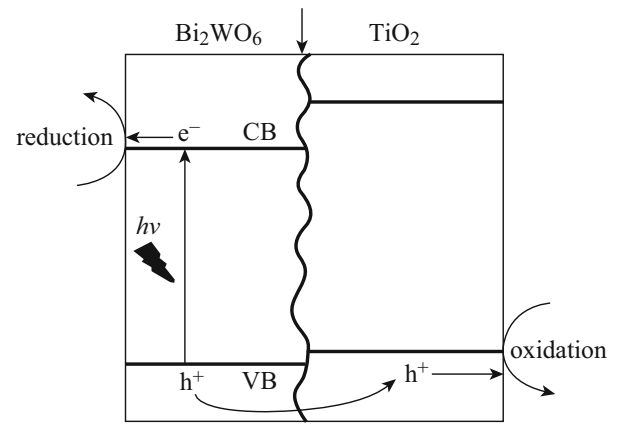

Fig. 5 Schematic interfacial electron transfer between $\mathrm{TiO}_{2}$ and $\mathrm{Bi}_{2} \mathrm{WO}_{6}[47]$

photoelectrochemical properties because of the overlapping in band gaps between two different photocatalysts, which could favor the charge carrier transfer and separation. Typical examples are the ones illustrated in Figs. 4, 5. The conduction band $(\mathrm{CB})$ of catalyst $\mathrm{A}\left(\mathrm{Bi}_{2} \mathrm{WO}_{6}\right)$ is more negative than the one of catalyst $\mathrm{B}\left(\mathrm{TiO}_{2}\right)$; therefore, the excited electrons from catalyst $\mathrm{B}\left(\mathrm{TiO}_{2}\right)$ can be quickly transferred to catalyst $\mathrm{A}\left(\mathrm{Bi}_{2} \mathrm{WO}_{6}\right)$. The valance band (VB) of catalyst $\mathrm{A}\left(\mathrm{Bi}_{2} \mathrm{WO}_{6}\right)$ is more positive than the one of catalyst $\mathrm{B}\left(\mathrm{TiO}_{2}\right)$, and the excited holes from catalyst $\mathrm{A}$ $\left(\mathrm{Bi}_{2} \mathrm{WO}_{6}\right)$ can be quickly transferred to catalyst $\mathrm{B}\left(\mathrm{TiO}_{2}\right)$. As a result, the excited electrons and holes can be separated and transferred quickly for efficient water splitting. This technique has been extensively applied in enhancing the photoelectrochemical performance of $\mathrm{TiO}_{2}$ through modification using visible-light responsive semiconductors such as $\mathrm{CdS}, \mathrm{Bi}_{2} \mathrm{WO}_{6}$, Rh-doped $\mathrm{SrTiO}_{3}$, etc. [46-49].

The above examples are related to binary hybrid systems for PEC water splitting. It should be noted that the CdS$\mathrm{TiO}_{2}-\mathrm{WO}_{3}$ ternary hybrid system for PEC water splitting has also been reported recently [50]. The cascaded electrons are transferred from $\mathrm{CdS}$ to $\mathrm{TiO}_{2}$ to $\mathrm{WO}_{3}$ through the interfacial potential gradient in the ternary hybrid conduction bands. The maximum photocurrent density of the ternary hybrid is up to $1.6 \mathrm{~mA} \mathrm{~cm} \mathrm{~cm}^{-2}$ (at $0 \mathrm{~V} \mathrm{Ag} / \mathrm{AgCl}$ ) under visible light irradiation, which is much higher than those of bare CdS and any binary hybrids.

Oxygen vacancy technique has often been applied to enhance the performance of $\mathrm{TiO}_{2}$ for PEC water splitting in recent years [51]. Oxygen vacancies can be produced through hydrogen treatment $[51,52]$. It can also be generated by annealing metal oxide under oxygen-deficient conditions [53]. In comparison with the hydrogen treatment method, this approach eliminates the potential influence of hydrogen impurities. The PEC performance of $\mathrm{TiO}_{2}$ electrodes can be enhanced by controlling the introduction of oxygen vacancies, which as shallow donors can significantly improve electrical conductivities of $\mathrm{TiO}_{2}$ nanosemiconductors.

Besides $\mathrm{TiO}_{2}$, many other metal-oxide photocatalysts such as $\mathrm{BiVO}_{4}, \mathrm{WO}_{3}, \mathrm{ZnO}$, etc. have invariably been attempted to be coated on substrate as photoanodes for PEC water splitting [17, 54-57]. External voltage is needed when $\mathrm{BiVO}_{4}$ or/and $\mathrm{WO}_{3}$ photoanodes are applied for PEC water splitting. This is because their conduct bands are more positive than the potential of hydrogen evolution. Heterojunction can be applied to improve their photoelectrochemical performance. For example, nanostructured $\mathrm{WO}_{3} / \mathrm{BiVO}_{4}$ heterojunction is prepared for PEC water splitting as shown in Fig. 6 [58]. $\mathrm{BiVO}_{4}$ layer was coated on $\mathrm{WO}_{3}$ nanorod array by spin coating. The charges can be quickly separated and transferred due to the energy diagram of $\mathrm{WO}_{3} / \mathrm{BiVO}_{4}$ heterojunction. Because of excellent properties of graphene oxides for electron transfer, they have often been used to improve the photoelectrochemical properties of semiconductors in recent years [59]. And some metal hydroxides such as $\mathrm{FeOOH}$ (Fig. 7), $\mathrm{NiOOH}$, and layered double hydroxide (LDH) have been reported as effective photoanode materials for PEC water splitting because the alignment reduced interface recombination at the junction between them and semiconductors, and created a more favorable Helmholtz layer potential drop at the semiconductor/electrolyte junction [16, 60, 61], which provides a hint for searching new materials in the field of PEC water splitting.

Owing to their narrow bandgap, some n-type metal sulfide [62-64] and oxynitride [65-67] photocatalysts can respond to visible light with long wavelength and appropriate band levels for water splitting, and therefore are chosen as photoanode materials for PEC water splitting in order to make better use of solar energy. CdS (Fig. 8) and other sulfides are often used in photoanodes as sensitizer for PEC water splitting [68]. However, the sulfides are not stable because of photocorrosion, which can be reduced by adding sacrificial agents [69]. Tantalum oxynitrides also show visible light absorption with long wavelength-yet they are not 


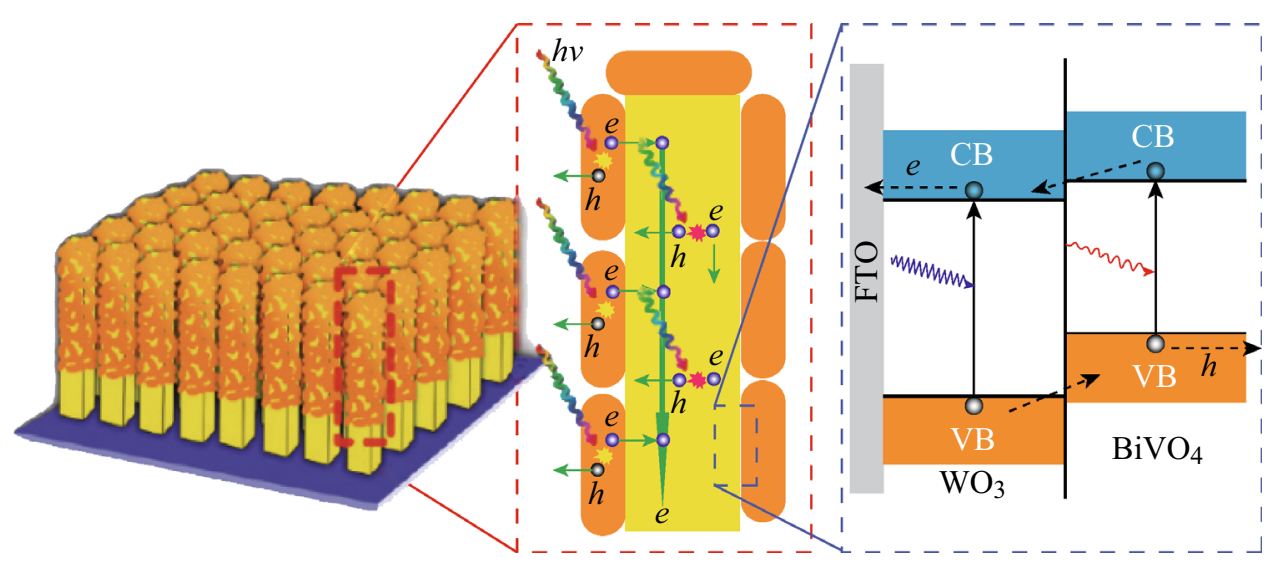

Fig. 6 The diagram of $\mathrm{BiVO}_{4} / \mathrm{WO}_{3}$ heterojunction and electron transport process [58]
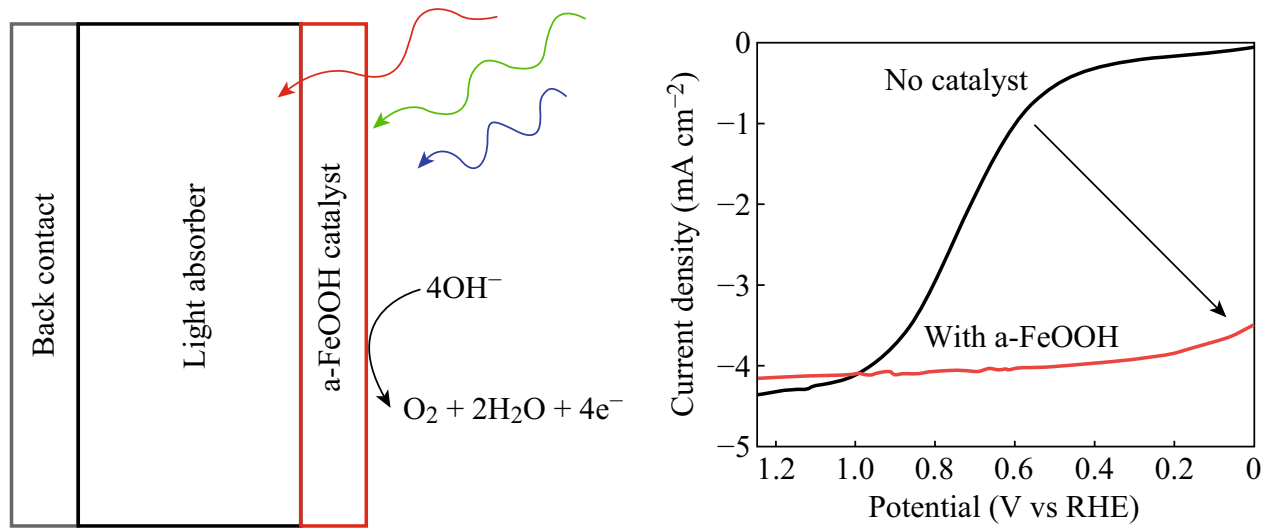

Fig. $7 \mathrm{FeOOH}$ as photoanode for photoelectrochemical water splitting [60]

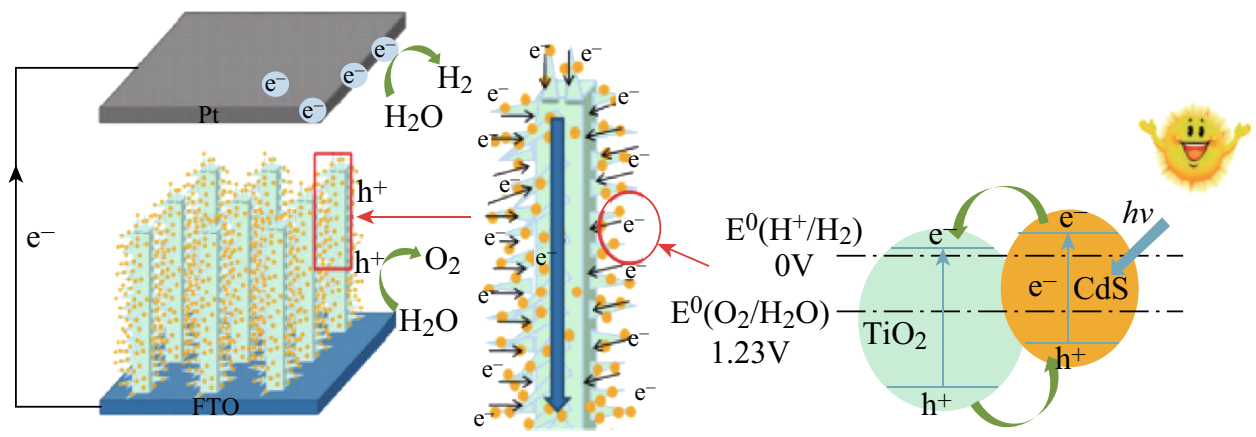

Fig. 8 The scheme of the nanostructure of the $\mathrm{CdS} / \mathrm{TiO}_{2}$ nanoarrays and charge-transfer mechanism [68]

stable and the intensity of absorption is low. Therefore, different techniques such as modification with cocatalysts, heterojunction, etc., have been developed to reduce the photocorrosion and enhance the PEC properties [66-68].

\subsection{Photocathode and Cathodic Semiconductors}

Photocathode usually comprises p-type semiconductor coated on conductive substrates in the PEC water splitting system. As shown in Fig. 9, under light illumination, water is reduced on the surface of semiconductor, while water is oxidized on the counter photoelectrode. From the electrochemical potential point of view, the conduction band edge of the photocatalysts should be more negative than the hydrogen evolution potential enabling the photocathode to generate hydrogen. Compared with the reports of $n$-type semiconductor photoanodes, there are fewer reports based on p-type semiconductor as photocathodes for PEC water splitting [70-77]. 


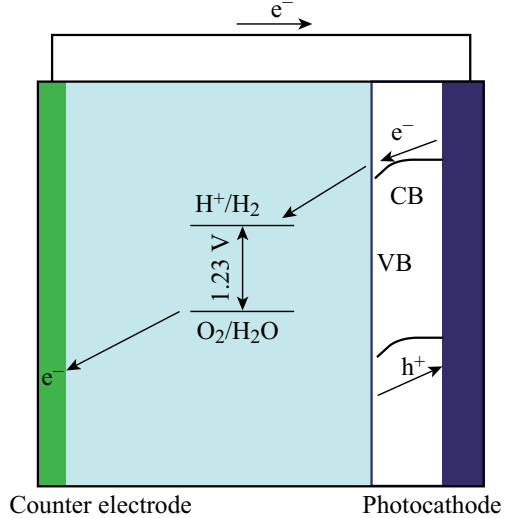

Fig. 9 Semiconductors coated on substrates as photocathode for PEC water splitting [15]

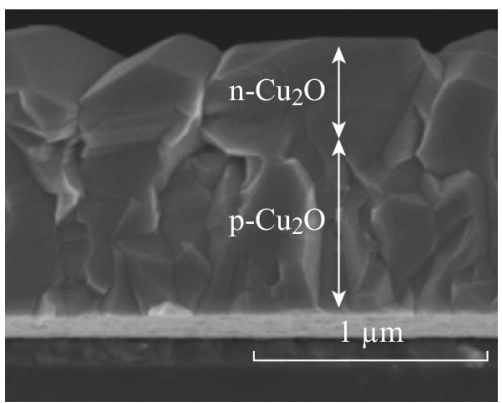

Fig. 10 SEM image of a p-n $\mathrm{Cu}_{2} \mathrm{O}$ homojunction [78]

$\mathrm{Cu}_{2} \mathrm{O}$ is a typical p-type semiconductor used as photoelectrode for PEC water splitting, while it readily gets degraded due to self-reduction by photogenerated electrons. $\mathrm{WO}_{3} / \mathrm{Cu}_{2} \mathrm{O}$ p-n junctions have been synthesized to reduce the self-reduction of $\mathrm{Cu}_{2} \mathrm{O}$ and enhance the PEC properties [77]. In addition, $\mathrm{p}-\mathrm{n}$ homojunctions have also been prepared to improve their PEC performance $[78,79]$. Colleen et al. [78] fabricated $\mathrm{p}-\mathrm{n} \mathrm{Cu}_{2} \mathrm{O}$ homojunction solar cells by electrochemically depositing an $\mathrm{n}-\mathrm{Cu}_{2} \mathrm{O}$ layer on a p- $\mathrm{Cu}_{2} \mathrm{O}$ layer as shown as in Fig. 10. The intrinsic doping levels of the prepared $\mathrm{p}-\mathrm{Cu}_{2} \mathrm{O}$ and $\mathrm{n}-\mathrm{Cu}_{2} \mathrm{O}$ layers were very low, and they made Ohmic junctions with $\mathrm{Cu}$ metal. The best cell performance (an $\eta$ of $1.06 \%$, a $V_{\mathrm{OC}}$ of $0.621 \mathrm{~V}$, an $I_{\mathrm{SC}}$ of $4.07 \mathrm{~mA} \mathrm{~cm}^{-2}$, and a fill factor of $42 \%$ ) was obtained, which was better than other $\mathrm{p}-\mathrm{n} \mathrm{Cu}_{2} \mathrm{O}$ homojunctions. Paracchino et al. reported that $\mathrm{Cu}_{2} \mathrm{O}$ photocathode, as shown in Fig. 11, which was protected against photocathodic decomposition in water by nanolayer of Aldoped zinc oxide and titanium dioxide and activated for hydrogen evolution with electrodeposited Pt nanoparticulates, showed photocurrents of up to $-7.6 \mathrm{~mA} \mathrm{~cm}^{-2}$ at a potential of $0 \mathrm{~V}$ versus the reversible hydrogen electrode at mild $\mathrm{pH}[80]$.

B-doped $\mathrm{Si}$ with the decoration of Pt, has often been used as a p-type photocathode for PEC water splitting [81,

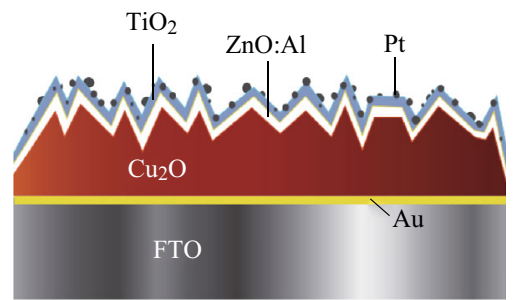

Fig. 11 Schematic representation of the electrode structure of the surface-protected $\mathrm{Cu}_{2} \mathrm{O}$ electrode [80]

82], and Pt-modified Si photovoltaic cell (Pt/SiPVC) based on $\mathrm{p}-\mathrm{n}$ radial junctions with a $\mathrm{p}$-type $\mathrm{Si}$ substrate has also been reported as an effective photocathode for PEC water splitting [19]. Si-based photoelectrodes for PEC water splitting has a potential prospect because of low-cost and abundant Si resource, while the efficiency should be further improved.

Recently, copper sulfides or selenides $\left(\mathrm{CuInS}_{2}, \mathrm{Cu}_{2-}\right.$ $\mathrm{ZnSnS}_{4}, \mathrm{Cu}(\mathrm{In}, \mathrm{Ga}) \mathrm{Se}_{2}$, etc.) have been reported as efficient p-type photocathodes for PEC water splitting under visible light $[74,75]$. However, they suffered from serious photocorrosion. Moriy et al. deposited $\mathrm{CdS}$ on $\mathrm{Cu}(\mathrm{In}$, $\mathrm{Ga}) \mathrm{Se}_{2}$ through chemical bath deposition (CBD) as shown in Fig. 12 [18]. The photocurrent increased due to the $\mathrm{p}-\mathrm{n}$ junctions formed between them, which accelerated the charge separation. Further, the $\mathrm{Pt} / \mathrm{CdS} / \mathrm{CuGaSe} \mathrm{Cl}_{2}$ electrode showed a stable photocurrent (about $4 \mathrm{~mA} \mathrm{~cm}^{-2}, 0.05 \mathrm{M}$ $\mathrm{Na}_{2} \mathrm{HPO}_{4}(\mathrm{aq})+0.05 \mathrm{M} \mathrm{NaH}_{2} \mathrm{PO}_{4}(\mathrm{aq}), \mathrm{pH} 7,150 \mathrm{~W} \mathrm{Xe}$ lamp, 0 Vvs RHE) under reductive conditions for more than 10 days under visible-light irradiation.

\subsection{Z-scheme System for PEC Water Splitting}

With suitable band structure, n-type semiconductors are usually used as photoanode and p-type semiconductors as photocathode for PEC water splitting. It is known that n-type semiconductor has a Fermi level near the conductor band (CB) edge and p-type semiconductor has a Fermi level near the valance band (VB) edge [19]. When n-type and p-type semiconductors are simultaneously used as photoanode and photocathode, respectively, (Z-scheme) as shown in Fig. 13, the mismatching Fermi levels could produce self-bias which can drive the excited electrons from photoanode to combine with the excited holes from photocathode. Meanwhile, water oxidation and reduction take place over the photoanode and photocathode, respectively. In the Z-scheme systems, the self-bias would act as an extra driving force for carriers' charge transfers and transportation while their performance is still governed by the materials and the competition between chemical reaction and recombination.

Ida et al. constructed a PEC water splitting using p-type $\mathrm{CaFe}_{2} \mathrm{O}_{4}$ as photocathode and n-type $\mathrm{TiO}_{2}$ as photoanode 


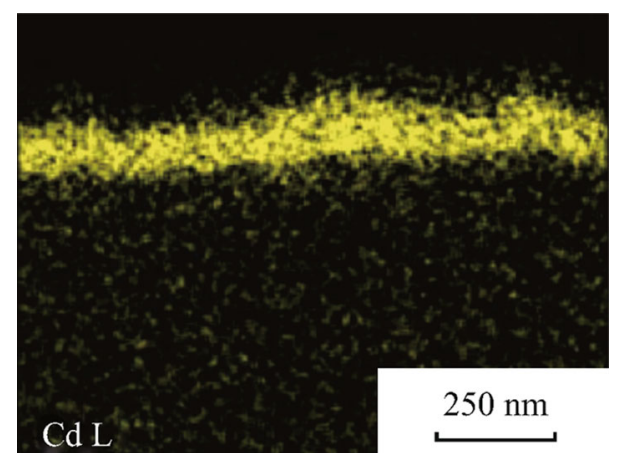

Fig. 12 EDX mapping of $\mathrm{CdS} / \mathrm{CuGaSe}_{2}$ sample with chemical bath deposition for $1 \mathrm{~min}$ [18]

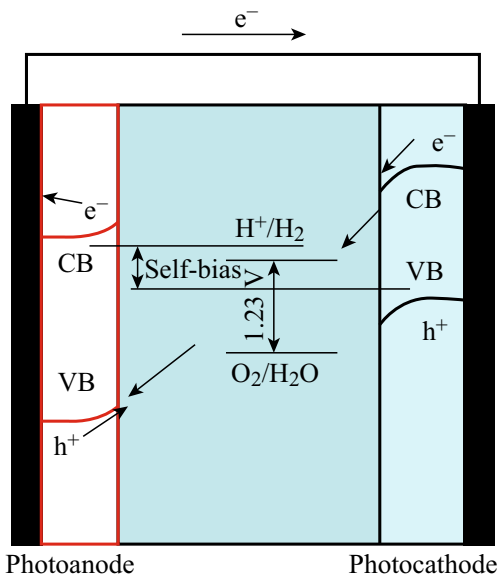

Fig. 13 n-type and p-type semiconductors coated on substrates as photoanode and photocathode, respectively, for PEC water splitting (Z-scheme) [15]

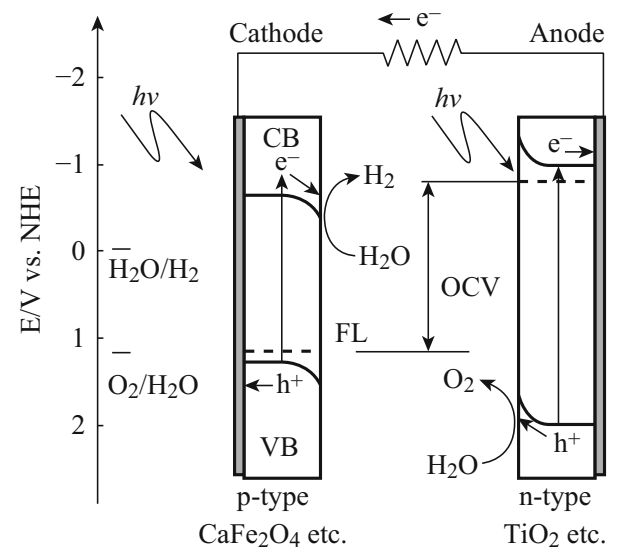

Fig. 14 Reaction and band model in photovoltaic cell using p-type $\mathrm{CaFe}_{2} \mathrm{O}_{4}$ and n-type $\mathrm{TiO}_{2}$ semiconductor electrodes [83]

[83]. As shown in Fig. 14, under illumination without external voltage, hydrogen and oxygen were produced from photocathode and photoanode, respectively, with a

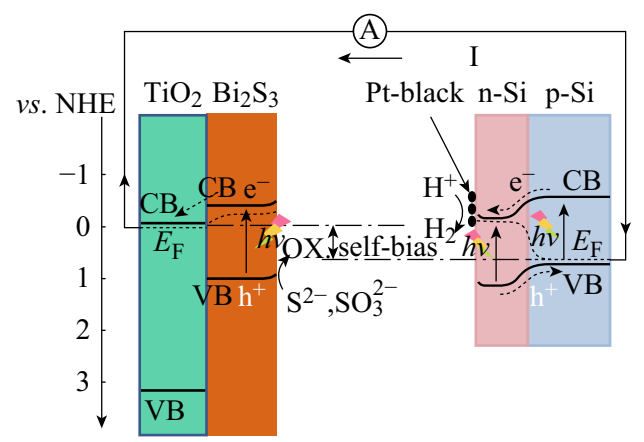

Photoanode: $\mathrm{Bi}_{2} \mathrm{~S}_{3} / \mathrm{TNA} \quad$ Photocathode: $\mathrm{Pt} / \mathrm{SiPVC}$

Fig. 15 The energy-level diagram of the self-biasing PEC cell assembled with $\mathrm{Bi}_{2} \mathrm{~S}_{3} / \mathrm{TNA}$ photoanode and $\mathrm{Pt} / \mathrm{SiPVC}$ photocathode under short-circuit situation [19]

short-circuit current of about $200 \mu \mathrm{A} \mathrm{cm}^{-2}$. However, this system is not responsive to visible light because $\mathrm{TiO}_{2}$ only responds to ultraviolet light. A PEC cell [84] made up of $\mathrm{WO}_{3}$ photoanode and $\mathrm{p}-\mathrm{GaInP}_{2}$ photocathode has been reported, both of which are responsive to visible light. However, the conduct band edge of $\mathrm{WO}_{3}$ (about $0.25 \mathrm{~V}$ vs. NHE) is more positive than the valance band of $\mathrm{p}-\mathrm{GaInP}_{2}$ (about $0 \mathrm{~V}$ vs. NHE), which restricts the charge transfer from photoanode to photocathode via external circuit. Furthermore, the $\mathrm{WO}_{3}$ films show relatively poor charge separation properties and weak visible-light absorbance. Thus, this PEC cell cannot split water till enough light intensity is applied. $\mathrm{TiO}_{2}$ itself could not respond to visible light. Zeng et al. used $\mathrm{Bi}_{2} \mathrm{~S}_{3}$-decorated $\mathrm{TiO}_{2}$ nanotube arrays as photoanode and Pt-modified Si photovoltaic cell (Pt/SiPVC) as photocathode [19]. Both of them could respond to visible light. As shown in Fig. 15, the conduction band edge of $\mathrm{TiO}_{2}$ (about $-0.05 \mathrm{~V}$ vs. NHE) is more negative than the valance band edge of $\mathrm{Pt} / \mathrm{SiPVC}$ (about $0.8 \mathrm{~V}$ vs. NHE). A self-bias of about $0.85 \mathrm{~V}$ is formed between two photoelectrodes for efficient spontaneous hydrogen evolution and electricity generation under visible light irradiation. However, this system for PEC water splitting needs to be added with sacrificial agents. Thus, an efficient Z-scheme system consisting visible-light responsive photocatalysts for PEC water splitting without addition of sacrificial agents needs to be developed.

\section{Conclusions and Future Perspective}

Photoelectrochemical devices comprising of visible-lightresponsive semiconductors have attracted great efforts in water splitting processes to obtain sustainable hydrogen, in search of a promising technique to combat the challenges from global climate change. The prospect of the PEC water splitting systems were highly limited by the nanostructured 
photocatalysts and their device configurations. The most important issues associated with the PEC devices lay on the sunlight absorbance, energy loss due to undesirable charge carrier recombination and photodegradation of the photoelectrodes. Along with the rapid and great development of nanomaterial science and semiconductor engineering, significant advances have been observed, which shed light on resolving the aforementioned challenges in the PEC water splitting in the recent decades, since the discovery of PEC water splitting by Honda and Fujisma in the 1970s.

Starting from brief introduction of the working mechanism and history of PEC system, this article overviewed the greatest progress in PEC water splitting systems comprising visible-light-responsive photocatalysts. The advantages and disadvantages of the emerging photoanodes and photocathodes were assessed with typical examples, to disclose the potentially effective strategies to promote the efficiency and stability of various PEC systems. Special attention was paid to the $\mathrm{TiO}_{2}$ nanotube arrays and modified $\mathrm{TiO}_{2}$ photoelectrodes, which can be responsive to visible light via doping with metal and/or nonmetal elements, creating lattice vacancies, and designing heterojunction or Schottky junctions by means of combining other semiconductors or nanoscaled metal particles. Such modifications would not only revise the band structures and energy alignment of $\mathrm{TiO}_{2}$ photoelectrodes in the PEC electrolyte solution but also introduce additional drivers that influence photogenerated charge carrier's separation and transfer. On the basis of advances in $\mathrm{TiO}_{2}$ photoelectrodes and PEC systems, other visible-light-responsive semiconductor photoelectrodes and Z-scheme systems were addressed. Among those strategies, heterojunctions and homojunctions were found to be more attractive for single photoelectrode due to the low cost and broad room to align the energy gradient across the semiconductor interface.

The recent advances in the photoelectrodes and their configurations have shed light on resolving the great challenges in PEC water splitting systems, in which one of the very promising solutions could be constructing Z-scheme PEC system involving suitable semiconductor photoanode and photocathode. With reasonable design, the photoexcited charge carriers may be quickly separated and transferred as a result of driven force generated from the self-bias among the separated photoelectrodes. More importantly, semiconductor with small bandgap even responsive to infrared light (heat) could be combined with the Z-scheme systems to harvest full spectrum sunlight. However, the Z-scheme PEC system is still in its early stage and demand further research input due to only limited report on this thriving configuration. The major obstacles in the Z-scheme systems are, similar to the normal PEC system, the efficient (deficient) light harvesting and (in)stability (due to photodegradation) of the semiconductors employed in the photoelectrodes.

Resistance photocorrosion is pivotal to realizing longterm application of PEC water splitting. Although introduction of sacrificial agents may somehow resist photocorrosion of the photoelectrodes, configurations of semiconductor heterojunctions have proven to be more promising because of their broader manufacturing possibility and low cost. In terms of the heterojunction principle, the Z-scheme systems may be stable due to the closed electric circuit involved; however, limited information can be found from the literature regarding their stability, suggesting greater efforts are still required in this area. Apparently, there is a significant step to apply PEC water splitting in hydrogen generation on industrial scale in the near future. However, spurred by global energy and environmental challenge, PEC water splitting is an ideal route to generate hydrogen with less-adverse impact on climate change, and hence, industrial-scale application of PEC water splitting would be the next-door event once the highly efficient and stable photoelectrodes with visiblelight-response could be developed, where the most promising PEC system might emerge from the breakthrough on Z-scheme system.

Acknowledgments This work was supported by the EU-China EcoFuel project (FP7, 246772) from the European Commission.

Open Access This article is distributed under the terms of the Creative Commons Attribution 4.0 International License (http://crea tivecommons.org/licenses/by/4.0/), which permits unrestricted use, distribution, and reproduction in any medium, provided you give appropriate credit to the original author(s) and the source, provide a link to the Creative Commons license, and indicate if changes were made.

\section{References}

1. A. Fujishima, K. Honda, Electrochemical photolysis of water at a semiconductor electrode. Nature 238(5358), 37-38 (1972). doi:10.1038/238037a0

2. Y. Li, J.Z. Zhang, Hydrogen generation from photoelectrochemical water splitting based on nanomaterials. Laser Photonics Rev. 4(4), 517-528 (2010). doi:10.1002/lpor.200910025

3. Y.R. Steven, A.H. Jonathan, S. Kimberly, D.J. Thomas, J.E. Arthur, J.H. Joep, G.N. Daniel, Wireless solar water splitting using silicon-based semiconductors and earth-abundant catalysts. Science 334(6056), 645-648 (2011). doi:10.1126/science. 1209816

4. N.A. Kelly, T.L. Gibson, Design and characterization of a robust photoelectrochemical device to generate hydrogen using solar water splitting. Int. J. Hydrog. Energ. 31(12), 1658-1673 (2006). doi:10.1016/j.ijhydene.2005.12.014

5. L.J. Minggu, W.R.W. Daud, M.B. Kassim, An overview of photocells and photoreactors for photoelectrochemical water splitting. Int. J. Hydrog. Energ. 35(11), 5233-5244 (2010). doi:10.1016/j.ijhydene.2010.02.133 
6. A. Kudo, Y. Miseki, Heterogeneous photocatalyst materials for water splitting. Chem. Soc. Rev. 38(1), 253-278 (2009). doi:10. 1039/B800489G

7. W.F. Shangguan, Progress in research of hydrogen production from water on photocatalysts with solar energy. Chinese J. Inorg. Chem. 17(5), 619-626 (2001)

8. Q. Li, B.D. Guo, J.G. Yu, J.R. Ran, B.H. Zhang, H.J. Yan, J.R. Gong, Highly efficient visible-light-driven photocatalytic hydrogen production of CdS-cluster-decorated graphene nanosheet. JACS 133(28), 10878-10884 (2011). doi:10.1021/ja2025454

9. X. Chen, W. Shangguan, Hydrogen production from water splitting on CdS-based photocatalysts using solar light. Front. Energy 7(1), 111-118 (2013). doi:10.1007/s11708-012-0228-4

10. X. Chen, W. Chen, P.B. Lin, Y. Yang, H.Y. Gao, J. Yuan, W. Shangguan, In situ photodeposition of nickel oxides on CdS for highly efficient hydrogen production via visible-light-driven photocatalysis. Catal. Commun. 36, 104-108 (2013). doi:10. 1016/j.catcom.2013.03.016

11. X. Chen, W. Chen, H.Y. Gao, Y. Yang, W. Shangguan, In situ photodeposition of $\mathrm{NiO}_{x}$ on CdS for hydrogen production under visible light: enhanced activity by controlling solution environment. Appl. Catal. B-Environ. 152, 68-72 (2014). doi:10.1016/j. apcatb.2014.01.022

12. A. Iwase, Y.H. Ng, R. Amal, A. Kudo, Solar hydrogen evolution using $\mathrm{CuGaS}_{2}$ photocathode improved by incorporating reduced graphene oxide. J. Mater. Chem. A 3, 8566-8570 (2015). doi:10. 1039/C5TA01237F

13. Y. Moriya, T. Takata, K. Domen, Recent progress in the development of (Oxy) nitride photocatalysts for water splitting under visible-light irradiation. Coordin. Chem. Rev. 257(13), 1957-1969 (2013). doi:10.1016/j.ccr.2013.01.021

14. K. Maeda, K. Domen, Photocatalytic water splitting: recent progress and future challenges. J. Phys. Chem. Lett. 1(18), 2655-2661 (2010). doi:10.1021/jz1007966

15. T. Hisatomi, J. Kubota, K. Domen, Recent advances in semiconductors for photocatalytic and photoelectrochemical water splitting. Chem. Soc. Rev. 43(22), 7520-7535 (2014). doi:10. 1039/C3CS60378D

16. T.W. Kim, K.S. Choi, Nanoporous $\mathrm{BiVO}_{4}$ photoanodes with dual-layer oxygen evolution catalysts for solar water splitting. Science 343(6174), 990-994 (2014). doi:10.1126/science. 1246913

17. X. Liu, F. Wang, Q. Wang, Nanostructure-based $\mathrm{WO}_{3}$ photoanodes for photoelectrochemical water splitting. Phys. Chem. Cheml. Phys. 14(22), 7894-7911 (2012). doi:10.1039/c2cp40976c

18. M. Moriya, T. Minegishi, H. Kumagai, M. Katayama, J. Kubota, K. Domen, Stable hydrogen evolution from CdS-modified $\mathrm{CuGaSe}_{2}$ photoelectrode under visible-light irradiation. JACS 135(10), 3733-3735 (2013). doi:10.1021/ja312653y

19. Q.Y. Zeng, J. Bai, J.H. Li, Y.P. Li, X.J. Li, B.X. Zhou, Combined nanostructured $\mathrm{Bi}_{2} \mathrm{~S}_{3} / \mathrm{TNA}$ photoanode and $\mathrm{Pt} / \mathrm{SiPVC}$ photocathode for efficient self-biasing photoelectrochemical hydrogen and electricity generation. Nano Energy 9, 152-160 (2014). doi:10.1016/j.nanoen.2014.06.023

20. K. Sivula, F.L. Formal, M. Grätzel, Solar water splitting: progress using hematite $\left(\alpha-\mathrm{Fe}_{2} \mathrm{O}_{3}\right)$ photoelectrodes. Chem. Sus. Chem. 4(4), 432-449 (2011). doi:10.1002/cssc.201000416

21. S. Yamane, N. Kato, S. Kojima, A. Imanishi, S. Ogawa, N. Yoshida, S. Nonomura, Y. Nakato, Efficient solar water splitting with a composite "n-Si/p-CuI/nip a-Si/np $\mathrm{GaP} / \mathrm{RuO}_{2}$ " semiconductor electrode. J. Phys. Chem. C 113(32), 14575-14581 (2009). doi:10.1021/jp904297v

22. D.J. Martin, P.J.T. Reardon, S.J.A. Moniz, J.W. Tang, Visible lightdriven pure water splitting by a nature-inspired organic semiconductor-based system. JACS 136(36), 12568-12571 (2014). doi:10. 1021/ja506386e
23. S.U. Khan, M. Al-Shahry, W.B. Ingler, Efficient photochemical water splitting by a chemically modified $\mathrm{n}-\mathrm{TiO}_{2}$. Science 297(5590), 2243-2245 (2002). doi:10.1126/science.1075035

24. Y.R. Smith, B. Sarma, S.K. Mohanty, M. Misra, Single-step anodization for synthesis of hierarchical $\mathrm{TiO}_{2}$ nanotube arrays onfoil and wire substrate for enhanced photoelectrochemical water splitting. Int. J. Hydrog. Energ. 38(5), 2062-2069 (2013). doi:10.1016/j.ijhydene.2012.11.045

25. C. Cheng, H. Zhang, W. Ren, W. Dong, Y. Sun, Three dimensional urchin-like ordered hollow $\mathrm{TiO}_{2} / \mathrm{ZnO}$ nanorods structure as efficient photoelectrochemical anode. Nano Energy 2(5), 779-786 (2013). doi:10.1016/j.nanoen.2013.01.010

26. Q. Gang, Akira watanabe, surface texturing of $\mathrm{TiO}_{2}$ film by mist deposition of $\mathrm{TiO}_{2}$ nanoparticles. Nano-Micro Lett. 5(2), 129-134 (2013). doi:10.1007/BF03353740

27. Z. Su, W. Zhou, F. Jiang, M. Hong, Anodic formation of nanoporous and nanotubular metal oxides. J. Mater. Chem. 22(2), 535-544 (2012). doi:10.1039/C1JM13338A

28. Y.R. Smith, R.S. Ray, K. Carlson, B. Sarma, M. Misra, Self-ordered titanium dioxide nanotube arrays: anodic synthesis and their photo/electro-catalytic applications. Materials 6(7), 2892-2957 (2013). doi:10.3390/ma6072892

29. O.K. Varghese, M. Paulose, C.A. Grimes, Long vertically aligned titania nanotubes on transparent conducting oxide for highly efficient solar cells. Nat. Nanotechnol. 4(9), 592-597 (2009). doi:10.1038/nnano.2009.226

30. X. Feng, K. Shankar, O.K. Varghese, M. Paulose, T.J. Latempa, C.A. Grimes, Vertically aligned single crystal $\mathrm{TiO}_{2}$ nanowire arrays grown directly on transparent conducting oxide coated glass: synthesis details and applications. Nano Lett. 8(11), 3781-3786 (2008). doi:10.1021/n1802096a

31. M. Ni, M.K.H. Leung, D.Y.C. Leung, K. Sumathy, A review and recent developments in photocatalytic water-splitting using $\mathrm{TiO}_{2}$ for hydrogen production. Renew. Sustain. Energy Rev. 11(3), 401-425 (2007). doi:10.1016/j.rser.2005.01.009

32. S. In, A. Orlov, R. Beng, F. Garcia, S.P. Jimenez, M.S. Tikhov, D.S. Wright, R.M. Lambert, Effective visible light-activated B-doped and $\mathrm{B}, \mathrm{N}$-codoped $\mathrm{TiO}_{2}$ photocatalysts. JACS 129(45), 13790-13791 (2007). doi:10.1021/ja0749237

33. S.G. Kumar, L.G. Devi, Review on modified $\mathrm{TiO}_{2}$ photocatalysis under UV/visible light: selected results and related mechanisms on interfacial charge carrier transfer dynamics. J. Phys. Chem. A 115(46), 13211-13241 (2011). doi:10.1021/jp204364a

34. Q. Zheng, B. Zhou, J. Bai, L. Li, Z. Jin, J. Zhang, J. Li, Y. Liu, W. Cai, X. Zhu, Self-organized $\mathrm{TiO}_{2}$ nanotube array sensor for the determination of chemical oxygen demand. Adv. Mater. 20(5), 1044-1049 (2008). doi:10.1002/adma.200701619

35. J.H. Park, S. Kim, A.J. Bard, Novel carbon-doped $\mathrm{TiO}_{2}$ nanotube arrays with high aspect ratios for efficient solar water splitting. Nano Lett. 6(1), 24-28 (2006). doi:10.1021/n1051807y

36. J. Xu, Y. Ao, M. Chen, D. Fu, Photoelectrochemical property and photocatalytic activity of $\mathrm{N}$-doped $\mathrm{TiO}_{2}$ nanotube arrays. Appl. Surf. Sci. 256(13), 4397-4401 (2010). doi:10.1016/j.apsusc.2010. 02.037

37. X. Tang, D. Li, Sulfur-doped highly ordered $\mathrm{TiO}_{2}$ nanotubular arrays with visible light response. J. Phys. Chem. C 112(14), 5405-5409 (2008). doi:10.1021/jp710468a

38. N. Lu, H. Zhao, J. Li, X. Quan, S. Chen, Characterization of boron-doped $\mathrm{TiO}_{2}$ nanotube arrays prepared by electrochemical method and its visible light activity. Sep. Purif. Technol. 62(3), 668-673 (2008). doi:10.1016/j.seppur.2008.03.021

39. R. Liang, A. Hu, J. Persic, Y.N. Zhou, Palladium nanoparticles loaded on carbon modified $\mathrm{TiO}_{2}$ nanobelts for enhanced methanol electrooxidation. Nano-Micro Lett. 5(3), 202-212 (2013). doi:10. 1007/BF03353751 
40. Y. Pu, G. Wang, K. Chang, Y. Ling, Y. Lin, B. Fitzmorris, C. Liu, $\mathrm{X}$. Lu, Y. Tong, J. Zhang, Y. Hsu, Y. Li, Au nanostructuredecorated $\mathrm{TiO}_{2}$ nanowires exhibiting photoactivity across entire UV-visible region for photoelectrochemical water splitting. Nano Lett. 13(8), 3817-3823 (2013). doi:10.1021/nl4018385

41. H.J. Kim, S.H. Lee, A.A. Upadhye, I. Ro, M.I. Tejedor-Tejedor, M.A. Anderson, W.B. Kim, G.W. Huber, Plasmon-enhanced photoelectrochemical water splitting with size-controllable gold nanodot arrays. ACS Nano 8(10), 10756-10765 (2014). doi:10. $1021 / \mathrm{nn} 504484 \mathrm{u}$

42. X. Zhang, Y. Liu, Z. Kang, 3D branched ZnO nanowire arrays decorated with plasmonic Au nanoparticles for high-performance photoelectrochemical water splitting. ACS Appl. Mater. Interf. 6(6), 4480-4489 (2014). doi:10.1021/am500234v

43. J.A. Seabold, K. Shankar, R.H.T. Wilke, M. Paulose, O.K. Varghese, C.A. Grimes, K. Choi, Photoelectrochemical properties of heterojunction $\mathrm{CdTe} / \mathrm{TiO}_{2}$ electrodes constructed using highly ordered $\mathrm{TiO}_{2}$ nanotube arrays. Chem. Mater. 20(16), 5266-5273 (2008). doi:10.1021/cm8010666

44. L. Yang, S. Luo, Y. Li, Y. Xiao, Q. Kang, Q. Cai, High efficient photocatalytic degradation of p-nitrophenol on a unique $\mathrm{Cu}_{2} \mathrm{O}$ / $\mathrm{TiO}_{2}$ p-n heterojunction network catalyst. Environ. Sci. Technol. 44(19), 7641-7646 (2010). doi:10.1021/es101711k

45. W. Siripala, A. Ivanovskaya, T.F. Jaramillo, S. Baeck, E.W. McFarland, $\mathrm{A} \mathrm{Cu}_{2} \mathrm{O} / \mathrm{TiO}_{2}$ heterojunction thin film cathode for photoelectrocatalysis. Sol. Energy Mat. Sol. C 77(3), 229-237 (2003). doi:10.1016/S0927-0248(02)00343-4

46. X. Gao, W. Sun, Z. Hu, G. Ai, Y. Zhang, S. Feng, F. Li, L. Peng, An efficient method to form heterojunction $\mathrm{CdS} / \mathrm{TiO}_{2}$ photoelectrodes using highly ordered $\mathrm{TiO}_{2}$ nanotube array films. J. Phys. Chem. C 113(47), 20481-20485 (2009). doi:10.1021/jp904320d

47. Q.C. Xu, D.V. Wellia, Y.H. Ng, R. Amal, T.T.Y. Tan, Synthesis of porous and visible-light absorbing $\mathrm{Bi}_{2} \mathrm{WO}_{6} / \mathrm{TiO}_{2}$ heterojunction films with improved photoelectrochemical and photocatalytic performances. J. Phys. Chem. C 115(15), 7419-7428 (2011). doi:10.1021/jp1090137

48. J. Zhang, J.H. Bang, C. Tang, P.V. Kamat, Tailored $\mathrm{TiO}_{2}-\mathrm{SrTiO}_{3}$ heterostructure nanotube arrays for improved photoelectrochemical performance. ACS Nano 4(1), 387-395 (2010). doi:10.1021/ nn901087c

49. C. Cheng, S.K. Karuturi, L. Liu, J. Liu, H. Li, L.T. Su, A.I.Y. Tok, H.J. Fan, Quantum-dot-sensitized $\mathrm{TiO}_{2}$ inverse opals for photoelectrochemical hydrogen generation. Small 8(1), 37-42 (2012). doi:10.1002/smll.201101660

50. H. Kim, J. Kim, W. Kim, W. Choi, Enhanced photocatalytic and photoelectrochemical activity in the ternary hybrid of $\mathrm{CdS} / \mathrm{TiO}_{2} /$ $\mathrm{WO}_{3}$ through the cascadal electron transfer. J. Phys. Chem. C 115(19), 9797-9805 (2011). doi:10.1021/jp1122823

51. G. Wang, Y. Ling, Y. Li, Oxygen-deficient metal oxide nanostructures for photoelectrochemical water oxidation and other applications. Nanoscale 4(21), 6682-6691 (2012). doi:10.1039/ c2nr32222f

52. G. Wang, H. Wang, Y. Ling, Y. Tang, X. Yang, R.C. Fitzmorris, C. Wang, J.Z. Zhang, Y. Li, Hydrogen-treated $\mathrm{TiO}_{2}$ nanowire arrays for photoelectrochemical water splitting. Nano Lett. 11(7), 3026-3033 (2011). doi:10.1021/nl201766h

53. U. Diebolda, J. Lehmana, T. Mahmouda, M. Kuhna, G. Leonardellib, W. Hebenstreitb, M. Schmidb, P. Vargab, Intrinsic defects on a $\mathrm{TiO}_{2}(110)(1 \times 1)$ surface and their reaction with oxygen: a scanning tunneling microscopy study. Surf. Sci. 411(1), 137-153 (1998). doi:10.1016/S0039-6028(98)00356-2

54. Q. Jia, K. Iwashina, A. Kudo, Facile fabrication of an efficient $\mathrm{BiVO}_{4}$ thin film electrode for water splitting under visible light irradiation. P. Natl. Acad Sci. USA 109(29), 11564-11569 (2012). doi:10.1073/pnas.1204623109
55. A. Wolcott, W.A. Smith, T.R. Kuykendall, Y. Zhao, J.Z. Zhang, Photoelectrochemical study of nanostructured $\mathrm{ZnO}$ thin films for hydrogen generation from water splitting. Adv. Funct. Mater. 19(12), 1849-1856 (2009). doi:10.1002/adfm.200801363

56. X. Yang, A. Wolcott, G. Wang, A. Sobo, R.C. Fitzmorris, F. Qian, J.Z. Zhang, Y. Li, Nitrogen-doped ZnO nanowire arrays for photoelectrochemical water splitting. Nano Lett. 9(6), 2331-2336 (2009). doi:10.1021/n1900772q

57. P. Cai, S. Zhou, D. Ma, S. Liu, W. Chen, S. Huang, $\mathrm{Fe}_{2} \mathrm{O}_{3^{-}}$ modified porous $\mathrm{BiVO}_{4}$ nanoplates with enhanced photocatalytic activity. Nano-Micro Lett. 7(2), 183-193 (2015). doi:10.1007/ s40820-015-0033-9

58. J. Su, L. Guo, N. Bao, C.A. Grimes, Nanostructured $\mathrm{WO}_{3} / \mathrm{BiVO}_{4}$ heterojunction films for efficient photoelectrochemical water splitting. Nano Lett. 11(5), 1928-1933 (2011). doi:10.1021/ n12000743

59. Y.H. Ng, A. Iwase, A. Kudo, R. Amal, Reducing graphene oxide on a visible-light $\mathrm{BiVO}_{4}$ photocatalyst for an enhanced photoelectrochemical water Splitting. J. Phys. Chem. Lett. 1(17), 2607-2612 (2010). doi:10.1021/jz100978u

60. W.D. Chemelewski, H. Lee, J. Lin, A.J. Bard, C.B. Mullins, Amorphous $\mathrm{FeOOH}$ oxygen evolution reaction catalyst for photoelectrochemical water splitting. JACS 136(7), 2843-2850 (2014). doi:10.1021/ja411835a

61. M. Shao, F. Ning, M. Wei, D.G. Evans, X. Duan, Hierarchical nanowire arrays based on $\mathrm{ZnO}$ core-layered double hydroxide shell for largely enhanced photoelectrochemical water splitting. Adv. Funct. Mater. 24(5), 580-586 (2014). doi:10.1002/adfm. 201301889

62. R. Xie, J. Su, L. Guo, $\mathrm{Ag}_{2} \mathrm{~S} / \mathrm{CdS}$ nanorod-array heterojunctions for efficient photoelectrochemical water splitting. Int. J. Nanotechnol. 10(12), 1115-1128 (2013). doi:10.1504/IJNT.2013.058569

63. G. Wang, X. Yang, F. Qian, J.Z. Zhang, Y. Li, Double-sided $\mathrm{CdS}$ and $\mathrm{CdSe}$ quantum dot co-sensitized $\mathrm{ZnO}$ nanowire arrays for photoelectrochemical hydrogen generation. Nano Lett. 10(3), 1088-1092 (2010). doi:10.1021/nl100250z

64. A.A. Tahir, M.A. Ehsan, M. Mazhar, K.G.U. Wijayantha, M. Zeller, A.D. Hunter, Photoelectrochemical and photoresponsive properties of $\mathrm{Bi}_{2} \mathrm{~S}_{3}$ nanotube and nanoparticle thin films. Chem. Mater. 22(17), 5084-5092 (2010). doi:10.1021/cm101642b

65. R. Abe, M. Higashi, K. Domen, Facile fabrication of an efficient oxynitride TaON photoanode for overall water splitting into $\mathrm{H}_{2}$ and $\mathrm{O}_{2}$ under visible light irradiation. JACS 132(34), 11828-11829 (2010). doi:10.1021/ja1016552

66. M. Higashi, K. Domen, R. Abe, Highly stable water splitting on oxynitride $\mathrm{TaON}$ photoanode system under visible light irradiation. JACS 134(16), 6968-6971 (2012). doi:10.1021/ja302059g

67. M. Higashi, K. Domen, R. Abe, Fabrication of efficient TaON and $\mathrm{Ta}_{3} \mathrm{~N}_{5}$ photoanodes for water splitting under visible light irradiation. Energy Environ. Sci. 4(10), 4138-4147 (2011). doi:10.1039/c1ee01878g

68. F. Su, J. Lu, Y. Tian, X. Ma, J. Gong, Branched $\mathrm{TiO}_{2}$ nanoarrays sensitized with $\mathrm{CdS}$ quantum dots for highly efficient photoelectrochemical water splitting. Phys. Chem. Chem. Phys. 15(29), 12026-12032 (2013). doi:10.1039/c3cp51291f

69. X. Cheng, G. Pan, X. Yu, T. Zheng, Preparation of CdS NCs decorated $\mathrm{TiO}_{2}$ nano-tubes arrays photoelectrode and its enhanced photoelectrocatalytic performance and mechanism. Electrochim. Acta 105, 535-541 (2013). doi:10.1016/j.electacta. 2013.05.040

70. J. Nian, C.C. Hu, H. Teng, Electrodeposited p-type $\mathrm{Cu}_{2} \mathrm{O}$ for $\mathrm{H}_{2}$ evolution from photoelectrolysis of water under visible light illumination. Int. J. Hydrogen Energ. 33(12), 2897-2903 (2008). doi:10.1016/j.ijhydene.2008.03.052 
71. A. Shalom, A. Heller, Efficient p-InP (Rh-H alloy) and p-InP (ReH Alloy) hydrogen evolving photocathodes. J. Electrochem. Soc. 129(12), 2865-2866 (1982). doi:10.1149/1.2123695

72. O. Khaselev, J.A. Turner, Electrochemical stability of p-GaInP 2 in aqueous electrolytes toward photoelectrochemical water splitting. J. Electrochem. Soc. 145(10), 3335-3339 (1998). doi: $10.1149 / 1.1838808$

73. O. Khaselev, J.A. Turner, A monolithic photovoltaic-photoelectrochemical device for hydrogen production via water splitting. Science 280(5362), 425-427 (1998). doi:10.1126/science.280. 5362.425

74. W. Gunawan, S. Septina, T. Ikeda, T. Harada, K. Minegishi, M. Domen, Matsumura, Platinum and indium sulfide-modified $\mathrm{CuInS}_{2}$ as efficient photocathodes for photoelectrochemical water splitting. Chem. Commun. 50(64), 8941-8943 (2014). doi:10. 1039/C4CC03634D

75. T. Kameyama, T. Osaki, K. Okazaki, T. Shibayama, A. Kudo, S. Kuwabata, T. Torimoto, Preparation and photoelectrochemical properties of densely immobilized $\mathrm{Cu}_{2} \mathrm{ZnSnS}_{4}$ nanoparticle films. J. Mater. Chem. 20(25), 5319-5324 (2010). doi:10.1039/c0jm00454e

76. D. Yokoyama, T. Minegishi, K. Maeda, M. Katayama, J. Kubota, A. Yamada, M. Konagai, K. Domen, Photoelectrochemical water splitting using a $\mathrm{Cu}(\mathrm{In}, \mathrm{Ga}) \mathrm{Se}_{2}$ thin film. Electrochem. Commun. 12(6), 851-853 (2010). doi:10.1016/j.elecom.2010.04.004

77. C.C. $\mathrm{Hu}$, J.N. Nian, H. Teng, Electrodeposited p-type $\mathrm{Cu}_{2} \mathrm{O}$ as photocatalyst for $\mathrm{H}_{2}$ evolution from water reduction in the presence of $\mathrm{WO}_{3}$. Sol. Energy Mat. Sol. C 92(9), 1071-1076 (2008). doi:10.1016/j.solmat.2008.03.012

78. C.M. McShane, K.S. Choi, Junction studies on electrochemically fabricated $\mathrm{p}-\mathrm{n} \mathrm{Cu}_{2} \mathrm{O}$ homojunction solar cells for efficiency enhancement. Phys. Chem. Chem. Phys. 14(17), 6112-6118 (2012). doi:10.1039/c2cp40502d

79. T. Jiang, T. Xie, W. Yang, L. Chen, H. Fan, D. Wang, Photoelectrochemical and photovoltaic properties of $\mathrm{p}-\mathrm{n} \mathrm{Cu}_{2} \mathrm{O}$ homojunction films and their photocatalytic performance. J. Phys. Chem. C 117(9), 4619-4624 (2013). doi:10.1021/jp311532s

80. A. Paracchino, V. Laporte, K. Sivula, M. Gratzel, E. Thimsen, Highly active oxide photocathode for photoelectrochemical water reduction. Nat. Mater. 10(6), 456-461 (2011). doi:10.1038/ nmat 3017

81. R.N. Dominey, N.S. Lewis, J.A. Bruce, D.C. Bookbinder, M.S. Wrighton, Improvement of photoelectrochemical hydrogen generation by surface modification of p-type silicon semiconductor photocathodes. JACS 104(2), 467-482 (1982). doi:10.1021/ ja00366a016

82. S.W. Boettcher, E.L. Warren, M.C. Putnam, E.A. Santori, D.T. Evans et al., Photoelectrochemical hydrogen evolution using $\mathrm{Si}$ microwire arrays. JACS 133(5), 1216-1219 (2011). doi:10.1021/ ja108801m

83. S. Ida, K. Yamada, T. Matsunaga, H. Hagiwara, Y. Matsumoto, T. Ishihara, Preparation of p-type $\mathrm{CaFe}_{2} \mathrm{O}_{4}$ photocathodes for producing hydrogen from water. JACS 132(49), 17343-17345 (2010). doi:10.1021/ja106930f

84. H. Wang, T. Deutsch, J.A. Turner, Direct water splitting under visible light with nanostructured hematite and $\mathrm{WO}_{3}$ photoanodes and a GaInP $\mathrm{P}_{2}$ photocathode. J. Electrochem. Soc. 155(5), F91F96 (2008). doi:10.1149/1.2888477 